\title{
A STUDY ON LEAN MANUFACTURING IMPLEMENTATION IN MALAYSIAN AUTOMOTIVE COMPONENT INDUSTRY
}

\author{
A. N. M. Rose ${ }^{1,2, a}$, B. Md. Deros ${ }^{2, b}$ and M. N. Ab. Rahman ${ }^{2, c}$ \\ ${ }^{1}$ Faculty of Mechanical Engineering, University Malaysia Pahang, \\ 26600 Pekan, Pahang, Malaysia \\ *Email: nasser@ump.edu.my \\ Phone: +6094246348; Fax: +609424622 \\ ${ }^{2}$ Faculty of Engineering and Built Environment, \\ Department of Mechanical and Material Engineering, \\ Universiti Kebangsaan Malaysia, 43600, UKM, Bangi, Malaysia
}

\begin{abstract}
Lean manufacturing is an extended version of the Toyota Production System (TPS). It was highlighted as the best practice in the 21st century. Therefore, top and senior management in manufacturing firms are encouraged to adopt and adapt lean principles and practices in running their respective firms. The main objective of this paper is to investigate the extent of lean manufacturing perception and implementation in the Malaysian automotive component industry. A survey questionnaire was developed to collect top and senior management views with respect to their perception, judgement and opinion on twenty four lean manufacturing (LM) practices. This preliminary survey was conducted at 30 Malaysian automotive component manufacturing firms. The survey results show that a large majority of respondents have a high perception of the importance of lean manufacturing practices. However, it was found that their actual LM implementation is still on the low side. In this study, the non-parametric test was used to analyze the level of perception and implementation of the twenty four LM practices. The analysis of the survey results revealed that there are significant differences between the level of perception of the importance of LM practices and their actual implementation.
\end{abstract}

Keywords: Lean manufacturing; practices and perception; automotive component industry; non-parametric.

\section{INTRODUCTION}

In the era of globalization, Malaysian manufacturers have been facing challenges to fulfil customer expectations, overcome the uncertainty of demand fluctuations and supplier capability (Wong et al., 2009). In a developing country, Malaysian automotive component firms have to strive for manufacturing excellence in order to be on a par with established foreign automotive players (Haniff, Ismail, Deros, Rahman, \& Kadirgama, 2011; Rose, Deros, \& Rahman, 2013). One of the strategies to be excellent and efficient in a manufacturing firm is by reducing the seven wastes: overproduction, waiting time, defects, non value added processing activities, excess of motion, high inventory and transportation (Melton, 2005). The elimination of these wastes is one of the principles of lean manufacturing (Ohno,1988). Lean manufacturing (LM) has been receiving a lot of attention in the automotive industry for achieving excellent manufacturing and it is now also considered to be the standard manufacturing mode for 
the 21st century (Rineheart, Huxley, and Robertson, 1997). Apart from that, lean manufacturing (LM) is said to be the best approach for all industries (Papadopoulu \& Ozbayrak, 2005). In the competitive environment, with the penetration of Chinese and Indian products into the Malaysian market, it is in the best interest of stakeholders, whether employees, customers or suppliers, to adopt the best management practice in order to compete in today's global marketplace. In addition, China has been predicted to be the biggest rival to any firm from the year 2008 onwards (Zen \& Williamson, 2003). Lean manufacturing is a generic process management philosophy derived mainly from the Toyota Production System (TPS) (Womack, Jones, \& Roos, 1990). The main objective of this paper is to investigate the extent of lean manufacturing perception and implementation in the Malaysian automotive component industry. The study investigates the level of perception and practice of $24 \mathrm{LM}$ practices. In addition, the paper also reveals the mean scores for each of the LM practices based on firm size and the number of years that LM has been implemented. An important contribution of this paper is that it includes the statistical analysis of LM practices, and their perception and implementation in Malaysian automotive component firms, allowing one to know how far Malaysian firms are aware of this management philosophy and its potential benefits.

\section{LITERATURE REVIEW}

There are 101 lean practices being practiced in industry (Pavnaskar et al., 2003). Large organizations do not have any difficulties in adopting LM practices and are likely to implement all of the LM practices, unlike small organizations (Shah \& Ward, 2003). The advantage of comprehensively implementing LM practices is the huge benefits gained in operational performance compared to the implementation of limited lean practices (Bhasin \& Burcher, 2006). SMEs will face difficulties in implementing all of the LM practices due to four possible constraints: leadership, financial, lean expertise and organization culture (Achanga et al., 2006). Therefore, one of the efforts which could be made by SMEs is to implement selected lean practices which are feasible for their firm's capability. Generally, researchers (Gunasekaran, Forker, \& Kobu, 2000; Kumar \& Antony, 2008) suggest that SMEs should concentrate on and implement lean practices which carry minimum costs and are feasible to implement, such as $5 \mathrm{~S}$, multifunction, continuous improvement and reduction in setup time. These practices are considered simple, easy and suitable to be managed internally. Explanation and guidance on lean practices implementation are very important to new firms including SMEs. This can provide them with basic knowledge on LM implementation. Therefore, to ensure new firms or SMEs in the automotive component industry benefit from LM implementation, there is a need to identify fundamental practices which are applicable to them. Comprehensive reading of the LM literature enables the authors to classify LM practices into three groups based on firm size, number of years with established LM, and piecemeal implementation such as $5 \mathrm{~S}$, preventive maintenance and multifunction employees (Shah \& Ward, 2003; Lee, 1997; Gunasekaran et al., 2000). Thus, firms should take into consideration their capability and capacity before embarking on LM. Rose, Deros, and Rahman (2010) proposed three categories of LM practices; basic, intermediate and advanced. This could perhaps assist new or SME firms to use it as a guide for LM implementation and will also overcome difficulty factors in LM implementation, such as lack of understanding and wrong methodology on LM practices (Pavnaskar, Gershenson, \& Jambekar, 2003). 
Various studies have been done on LM practices, such as based on lean bundles, firm sizes, operation performance, infrastructure and location (Ferdousi \& Ahmed, 2009; Matson \& Matson, 2007; Shah \& Ward, 2007; White et al., 1999; Lee, 1997; Sakakibara et al., 1997). None of those studies focused on the feasible lean practices which can be applied as a guide to the new company or SMEs. The study of lean manufacturing in Malaysia is still limited (Wong, Wong, \& Ali, 2009) and there is a good opportunity for researchers to explore how LM can be implemented here. Therefore in this study the authors attempt to explore the extent of LM implementation in the Malaysian automotive component industry. This study is quite similar to other studies (Shah \& Ward, 2007), except that the number of LM practices is different and most of the studied LM practices are relevant to SMEs. A comprehensive review of LM practices implementation based on past literature has provided twenty four (24) LM practices which are considered very relevant to the scope of study. Due to limited space, the authors only highlight ten critical practices based on the highest mean score.

\section{RESEARCH METHODOLOGY}

The research methodology used was a survey questionnaire. The questionnaire consists of two parts. The first part asked about the company's background. The second part asked about the company's perception and implementation on 24 lean manufacturing practices. All questions were structured as closed. The questionnaire was validated by 10 experts, comprising academicians and practitioners. There was face to face discussion with the experts to ensure that all comments were clearly understood before being distributed to respondents. All experts were selected based on their vast experience in this area and all had working experience of more than 20 years. Based on the experts' comment, alterations were made to an earlier questionnaire on a few items such as questionable layout, ambiguous words and finally on lean manufacturing practices.

The list of respondents was obtained from the FMM-MATRADE Industry Directory (Automotives 2009/2010), SME Corp. and the Proton database. Two hundred and ninety five (295) manufacturers were identified, excluding the car assembly industry such as Proton, Perodua, Naza etc. As a preliminary study, 100 firms were selected which comprised large, medium and small firms. The questionnaires were distributed by post and addressed to the head of the manufacturing and quality department. These individuals were considered as best positioned, being directly involved with lean manufacturing implementation in this industry. Each of the distributed questionnaires included a stamped and self-addressed envelope. The respondents were given three weeks to respond. If there was no response, a follow-up letter was sent as a reminder. Apart from that, email and phone calls were used to increase the participation from them. Initially, the response rate was very poor, with about 5 responses $(5 \%)$. This reflected the fact that the response rate for a questionnaire survey is quite low, which is considered not unusual in Malaysia (Jusoh, Ibrahim, \& Zainuddin, 2008). Due to this poor response to the mail survey, the second alternative was carried out by distributing the questionnaire to respondents during an LM forum which was conducted at a Malaysian government body. Finally, a total of 30 responses were received, which is valid for statistical analysis. Phone calls and email were used to reach those who failed to answer any questions. This paper is based on the pilot study results and is considered as a preliminary study before embarking on a larger number of respondents. 


\section{RESULTS AND DISCUSSION}

Table 1 shows the profile for the respondent companies in terms of their size, type of certification, type of ownership, type of product, company age and the number of years that they have implemented lean manufacturing. It can be seen that only 9 firms $(30 \%)$ were SMEs, while the remainder were large organizations. The classification of the companies' size was based on the definition provided by SMECorp. In this research, large companies are those that have more than 150 employees in total, whereas an SME is categorized as having less than 150 employees. Most of the respondents were Malaysian firms, that is, 20 firms $(66.7 \%)$, whereas 7 firms $(23.3 \%)$ were foreignowned and the remaining 3 firms (10\%) were joint ventures. All firms had TS 19649 certification and 15 firms (50\%) had another certification on ISO 9001. The majority of these firms produced metal products, that is 9 firms (30\%), followed by firms producing plastic products - 7 firms $(23.3 \%)$, electronic parts - 4 firms (13.3\%), rubber parts - 4 firms $(13.3 \%)$, mechanical parts - 1 firm (3.3\%), and the remaining 5 firms $(16.7 \%)$ were producing other items. Twenty firms $(66.7 \%)$ had been established for more than 15 years, 8 firms (26.7\%) between 10 and 15 years, and the remaining 2 firms were between 5 to 10 years. Most of the respondents had implemented lean manufacturing for less than 3 years - 14 firms (46.7\%), and the remaining 16 firms had implemented LM for more than 3 years.

Table 1. Profiles of respondent companies.

\begin{tabular}{|c|c|c|c|c|c|}
\hline Description & Category & Freq (\%) & Description & Category & Freq (\%) \\
\hline \multirow[t]{2}{*}{ Company size } & SME & $9(30 \%)$ & $\begin{array}{l}\text { Type of } \\
\text { certification }\end{array}$ & TS16949 & $30(100 \%)$ \\
\hline & Large & $21(70 \%)$ & & ISO9001 & $15(50 \%)$ \\
\hline \multirow{6}{*}{$\begin{array}{l}\text { Type of } \\
\text { ownership }\end{array}$} & Malaysian & $20(66.7)$ & Type of products & Metal & $9(30 \%)$ \\
\hline & Foreign & $7(23.3 \%)$ & & Plastics & $7(23.3 \%)$ \\
\hline & $\begin{array}{l}\text { Joint } \\
\text { Venture }\end{array}$ & $3(10 \%)$ & & Electronics & $4(13.3 \%)$ \\
\hline & & & & Rubber & $4(13.3 \%)$ \\
\hline & & & & Mechanical & $1(3.3 \%)$ \\
\hline & & & & Others & $5(16.7 \%)$ \\
\hline \multirow[t]{3}{*}{$\begin{array}{l}\text { No. of years } \\
\text { established }\end{array}$} & $5-10$ & $2(6.7 \%)$ & $\begin{array}{l}\text { No. of years LM } \\
\text { implementation }\end{array}$ & $<3$ years & $14(46.7 \%)$ \\
\hline & $\begin{array}{l}>10 \text { and }< \\
15\end{array}$ & $8(26.7)$ & & $>3$ and $<5$ & $8(26.7 \%)$ \\
\hline & $>15$ & $20(66.7)$ & & $>5$ years & $8(26.7 \%)$ \\
\hline
\end{tabular}

Out of the $24 \mathrm{LM}$ practices, only 10 were presented in this paper, namely those for which there was a high mean score for the level of perception and practices, as highlighted in Table 2. In this part, the respondents were asked about their perception and the extent of lean manufacturing practices being implemented in their firms. The level of perception was measured with a scale of $1=$ not important to $5=$ very important, whereas the level of implementation was measured with a scale $1=$ no implementation to $5=$ high implementation. A higher mean score on the level of perception and implementation implies that LM practices are very important and extensively practiced by the respondent. The range of mean scores for level of perception on LM practices 
was 3.667 to 4.867 . The highest score for LM practices was $5 \mathrm{~S}$, followed by Kaizen and standardization of works, whereas the lowest score was focused factory (3.667). This indicates that these LM practices were very important in LM implementation, thus indicating that 5S, Kaizen and standardization need to be implemented in all firms, no matter what their size is. Meanwhile, the range of mean scores for the level of implementation was 2.833 to 4.233 . The highest score was display charts, followed by Kaizen. This is similar to ceramics firms in Spain, which used the display chart extensively for internal communication (Bonavia \& Marin, 2006). The advantage of the display chart is that it is easy to manage, requires less investment and can perhaps be implemented by any firm. The Kaizen mean score revealed that continuous improvement activities were highly practiced by all firms, indicating that they're striving for excellence to eliminate all manufacturing waste. However, the two lowest scores were focused factory and MRP/ERP adaptation to JIT.

Table 2. Mean perception and extent of practice of the lean manufacturing practices

\begin{tabular}{|c|c|c|c|c|c|c|c|}
\hline Perception & Mean & $\begin{array}{c}\text { Std. } \\
\text { Deviation }\end{array}$ & Rank & Practice & Mean & $\begin{array}{c}\text { Std. } \\
\text { Deviation }\end{array}$ & Rank \\
\hline $5 \mathrm{~S}$ & 4.867 & 0.346 & 1 & $5 \mathrm{~S}$ & 3.933 & 0.980 & 4 \\
\hline Kaizen & 4.867 & 0.434 & 2 & Kaizen & 4.133 & 0.730 & 2 \\
\hline Standardization & 4.667 & 0.547 & 3 & Standardization & 4.133 & 0.819 & 3 \\
\hline $\begin{array}{l}\text { Preventive } \\
\text { maintenance }\end{array}$ & 4.600 & 0.498 & 4 & $\begin{array}{l}\text { Preventive } \\
\text { maintenance }\end{array}$ & 3.767 & 0.817 & 7 \\
\hline Reduce setup time & 4.600 & 0.675 & 5 & $\begin{array}{l}\text { Reduce setup } \\
\text { time }\end{array}$ & 3.733 & 0.868 & 9 \\
\hline Display charts & 4.567 & 0.504 & 6 & Display charts & 4.233 & 0.626 & 1 \\
\hline Improvement team & 4.567 & 0.817 & 7 & $\begin{array}{l}\text { Improvement } \\
\text { team }\end{array}$ & 3.867 & 1.042 & 6 \\
\hline DSA & 4.433 & 0.728 & 8 & DSA & 3.733 & 0.944 & 10 \\
\hline Takt Time & 4.433 & 0.728 & 9 & Takt Time & 3.767 & 0.935 & 8 \\
\hline PDCA & 4.433 & 0.858 & 10 & PDCA & 3.933 & 1.014 & 5 \\
\hline Poka-yoke & 4.367 & 0.765 & 11 & Poka-yoke & 3.433 & 1.006 & 19 \\
\hline Quality circle & 4.300 & 0.877 & 12 & Quality circle & 3.433 & 1.104 & 18 \\
\hline Kanban & 4.300 & 1.055 & 13 & Kanban & 3.200 & 1.400 & 22 \\
\hline $\begin{array}{l}\text { Multifunction } \\
\text { employee }\end{array}$ & 4.300 & 1.055 & 14 & $\begin{array}{l}\text { Multifunction } \\
\text { employee }\end{array}$ & 3.400 & 1.003 & 20 \\
\hline SPC & 4.233 & 0.679 & 15 & SPC & 3.633 & 0.809 & 12 \\
\hline Andon & 4.233 & 0.971 & 16 & Andon & 3.633 & 1.217 & 13 \\
\hline Small lot & 4.167 & 1.053 & 17 & Small lot & 3.567 & 0.935 & 15 \\
\hline One piece flow & 4.100 & 0.960 & 18 & One piece flow & 3.467 & 1.074 & 16 \\
\hline $\begin{array}{l}\text { Production } \\
\text { leveling }\end{array}$ & 4.067 & 0.740 & 19 & $\begin{array}{l}\text { Production } \\
\text { leveling }\end{array}$ & 3.433 & 0.935 & 17 \\
\hline Project room & 4.067 & 0.785 & 20 & Project room & 3.733 & 1.112 & 11 \\
\hline VSM & 4.067 & 0.944 & 21 & VSM & 3.600 & 0.855 & 14 \\
\hline Cell layout & 3.867 & 0.900 & 22 & Cell layout & 3.400 & 1.132 & 21 \\
\hline $\begin{array}{l}\text { MRP adaptation to } \\
\text { JIT }\end{array}$ & 3.733 & 1.081 & 23 & $\begin{array}{l}\text { MRP adaptation } \\
\text { to JIT }\end{array}$ & 2.833 & 1.117 & 24 \\
\hline Focused factory & 3.667 & 0.758 & 24 & Focused factory & 3.167 & 0.986 & 23 \\
\hline
\end{tabular}

The next analysis was to identify whether company size could influence the level of perception and practice on LM practices by using the Wilcoxon test. This is a non-parametric test which is designed to test repeated measures on two occasions or 
under two different conditions like perception and practice. Table 3 shows the Wilcoxon test analysis result of LM practices. All of them were statistically significant at $\alpha<$ 0.01 , in terms of the practiced and perceived importance, except for project room (obeya). This practice is not highlighted in Table 3 because the mean score for perception and practice was less than the others shown in Table 2. The difference between the perceived and practiced levels on LM practices shows that the level of understanding of LM implementation is still at the initial stage, and perhaps those firms lacked confidence in this system (Bhasin \& Burcher, 2006). Then, the second statistical analysis used was a Mann-Whitney test to identify any statistically significant relationship between the mean value of perception and practice and firm size, i.e., SMEs and large firms. Table 4 shows the details of the comparison between SMEs and large firms against the level of perception and practice.

Table 3. Differences between perception and practices on LM using Wilcoxon Test.

\begin{tabular}{lcc}
\hline \multicolumn{1}{c}{ Lean manufacturing practices } & $\mathrm{Z}$ & Sig. \\
\hline Reduce machine/tooling setup time & -3.963 & $* *$ \\
Standardization of operation & -3.087 & $* *$ \\
Kaizen & -3.787 & $* *$ \\
5S & -3.696 & $* *$ \\
Improvement team activities & -3.460 & $* *$ \\
Preventive maintenance program & -4.134 & $* *$ \\
Visual control - display charts & -2.500 & $* *$ \\
Daily schedule adherence & -3.535 & $* *$ \\
TAKT time & -3.377 & $* *$ \\
Plan Do Check Action (PDCA) & -2.976 & $* *$
\end{tabular}

Notes: Sig., significance level on Wilcoxon test: ${ }^{*} * \alpha<1 \%$; ${ }^{*} \alpha<5 \%$; ns: not significant.

Table 4. Differences in level of perception and practices against company size using Mann-Whitney

\begin{tabular}{lcccccc}
\hline \multicolumn{1}{c}{ Lean manufacturing practices } & \multicolumn{3}{c}{ SMEs } & \multicolumn{3}{c}{ Large } \\
\cline { 2 - 7 } & $\mathrm{Z}$ & $\mathrm{P}$ & Sig. & $\mathrm{Z}$ & $\mathrm{P}$ & Sig. \\
Reduce machine/tooling setup time & -2.271 & 0.023 & $*$ & -3.286 & 0.001 & $* *$ \\
Standardization of operation & -1.890 & 0.059 & $\mathrm{~ns}$ & -2.495 & 0.013 & $*$ \\
Kaizen & -2.070 & 0.038 & $*$ & -3.217 & 0.001 & $* *$ \\
5S & -2.081 & 0.037 & $*$ & -3.140 & 0.002 & $* *$ \\
Improvement team activities & -1.897 & 0.058 & $\mathrm{~ns}$ & -2.877 & 0.004 & $* *$ \\
Preventive maintenance program & -2.333 & 0.020 & $*$ & -3.448 & 0.001 & $* *$ \\
Visual control - display charts & -1.667 & 0.096 & $\mathrm{~ns}$ & -1.890 & 0.059 & $\mathrm{~ns}$ \\
Daily schedule adherence & -2.060 & 0.039 & $*$ & -2.919 & 0.004 & $* *$ \\
TAKT time & -1.857 & 0.063 & $\mathrm{~ns}$ & -2.801 & 0.005 & $* *$ \\
Plan Do Check Action (PDCA) & 0.000 & 1.000 & $\mathrm{~ns}$ & -3.274 & 0.001 & $* *$ \\
\hline
\end{tabular}

Notes: Sig., significance level on Mann-Whitney test: ${ }^{*} \alpha<1 \%$; ${ }^{*} \alpha<5 \%$; ns: not significant.

Ten practices were identified as statistically significant between perception and practice: reduce machine setup time, Kanban, Kaizen, 5S, quality circle, preventive maintenance, daily schedule adherence, poka-yoke, MRP/ERP adaptation to JIT and statistical process control for SMEs, as shown in Table 3. The level of firms' perception shows that SMEs are aware of the importance of LM practices, yet the actual 
implementation of these practices was at moderate levels, in the range of a mean value of 2.556 to 3.889. Perhaps SMEs faced constraints in providing the resources to manage LM implementation. In addition, SMEs may have financial, manpower, and skills constraints which limit their ability to implement extensively (Achanga et al., 2006). Similarly, the levels of perception and practice for large firms were statistically significant on all of the LM practices except for display charts and project room. Surprisingly, the levels of perception and practice for large companies were statistically insignificant on those two practices. Ideally, large firms should have at least similar judgments on the level of perception and practice. The authors' point of view was that large firms were very strong on organizational resources such as financial, number of employees, and skills, which could allow them to easily enforce the implementation of LM practices. The last statistical analysis was to identify any significance in the level of perception and extent of practice with LM practices based on the number of years of LM implementation. The number of years was categorized into three categories; less than 3 years, between 3 and 5 years and more than 5 years. The result in Table 5 shows that the level of perception and practice for those companies which had implemented LM for less than 3 years and between 3 and 5 years was significant in all LM practices except visual control, PDCA, and standardization of operation. However, the companies which had implemented LM for more than 5 years showed only Kaizen as statistically significant. This result could suggest that the longer establishment of LM in these companies might help employees to understand each of the LM practices in depth. The perceived importance and practices of these companies had the same score.

Table 5. Differences between perception and practice of LM practices based on number of years of LM implementation using Wilcoxon Test.

\begin{tabular}{|c|c|c|c|c|c|c|c|c|c|}
\hline \multirow{2}{*}{$\begin{array}{l}\text { Lean manufacturing } \\
\text { practices }\end{array}$} & \multicolumn{3}{|c|}{$<3$ years } & \multicolumn{3}{|c|}{$3-5$ years } & \multicolumn{3}{|c|}{$>5$ years } \\
\hline & $\mathrm{Z}$ & $\mathrm{P}$ & Sig. & $\mathrm{Z}$ & $\mathrm{P}$ & Sig. & $\mathrm{Z}$ & $\mathrm{P}$ & Sig. \\
\hline $\begin{array}{l}\text { Reduce } \\
\text { machine/tooling } \\
\text { setup time }\end{array}$ & -2.714 & 0.007 & $* *$ & -2.460 & 0.014 & $*$ & -1.890 & 0.059 & ns \\
\hline $\begin{array}{l}\text { Standardization of } \\
\text { operation }\end{array}$ & -2.646 & 0.008 & $* *$ & -1.732 & 0.083 & ns & -1.134 & 0.257 & ns \\
\hline Kaizen & -2.887 & 0.004 & $* *$ & -.2 .000 & 0.046 & $*$ & -2.000 & 0.046 & $*$ \\
\hline $5 \mathrm{~S}$ & -2.683 & 0.007 & $* *$ & -2.121 & 0.034 & $*$ & -1.732 & 0.083 & ns \\
\hline $\begin{array}{l}\text { Improvement team } \\
\text { activities }\end{array}$ & -2.310 & 0.021 & $*$ & -2.060 & 0.039 & $*$ & -1.633 & 0.102 & ns \\
\hline $\begin{array}{l}\text { Preventive } \\
\text { Maintenance } \\
\text { program }\end{array}$ & -2.714 & 0.007 & $* *$ & -2.640 & 0.008 & $* *$ & -1.857 & 0.063 & ns \\
\hline $\begin{array}{l}\text { Visual control - } \\
\text { display charts }\end{array}$ & -1.508 & 0.132 & ns & -2.000 & 0.046 & $*$ & -1.000 & 0.317 & ns \\
\hline $\begin{array}{l}\text { Daily schedule } \\
\text { adherence }\end{array}$ & -2.598 & 0.009 & $* *$ & -2.060 & 0.039 & $*$ & -1.414 & 0.157 & ns \\
\hline TAKT time & -2.588 & 0.010 & $*$ & -2.070 & 0.038 & $*$ & -0.577 & 0.564 & ns \\
\hline $\begin{array}{l}\text { Plan Do Check } \\
\text { Action (PDCA) }\end{array}$ & -1.732 & 0.083 & $\mathrm{~ns}$ & -1.890 & 0.059 & ns & -1.732 & 0.083 & ns \\
\hline
\end{tabular}

Notes: Sig., significance level on Wilcoxon test: $* * \alpha<1 \%$; $\alpha<5 \%$; ns: not significant. 
This study has provided important findings on the extent of LM implementation in Malaysian automotive component firms. The level of perception and implementation of LM practices was found to be significant especially in those companies which had implemented LM for less than 5 years. This result suggests that the respondents were aware of LM practices and some of them were practiced accordingly. The respondents in this study had implemented a varying degree of LM practices based on the firm size and the number of years of implementation. The mean scores for level of LM implementation were found to be high in the companies which had implemented LM for more than 5 years. This shows that the firms involved for longer with LM will have a strong tendency to implement comprehensive LM practices. However, new firms which are interested in implementing LM could start with fundamental practices such as Kaizen, 5S, VSM, quality circle, reduce setup time, multifunction skill and preventive maintenance. The adoption of these practices will strengthen the LM foundation and can be considered as preliminary practices before launching advanced practices such as small lot sizes and one piece flow. Therefore, it is suggested that automotive component firms should implement all of the LM practices in order to gain the full benefits. This can be implemented through a systematic approach by implementing basic, intermediate and advanced practices within a planned time frame. The preliminary survey result also shows that the perceived importance and extent of practice of LM practices were statistically significant, no matter what the size of the company. This suggests that the respondent companies were implementing LM practices gradually and at the same time continuing to learning the methodology of LM practices, especially in firms that had implemented LM for less than 5 years. Most of the companies which had implemented LM for more than 5 years showed the same levels of perception and extent of practice of LM practices. As an example, in Table 5 the practice of reduce machine setup time was not significant in companies which had implemented LM for more than 5 years, compared to those with less than 5 years. This shows that the established lean company knows the importance of the LM practices and practices them accordingly. However, rating a practice as 'low' in importance or 'not practiced' does not suggest that the practice is not important, but perhaps that the practice could not be implemented extensively due to organizational constraints, especially in SMEs. Therefore, government bodies such as SMECorp or the Malaysian Automotive Institute (MAI) should support LM implementation in the Malaysian automotive component industry by providing training and incentives. In order to validate this research, a future study will be carried out on a larger number of respondents.

\section{CONCLUSION}

This paper has provided a view related to a pilot study on the current status of the Malaysian automotive component industry on the level of perception and implementation of LM. Most of the surveyed companies agreed on the importance of lean practices in the their companies, but the level of implementation was not perceived by them in the same ways. This can be seen in Tables 3, 4 and 5, which show that most of the practices were statistically different between their perceived and practiced scores. These companies were perhaps unable to implement LM due to resources constraints such as financial, manpower or time. In order to understand in depth the difference between LM as perceived and practiced, a large-scale analysis and case study need to be arranged in the next study. Hopefully, the next study will be able to enhance the findings and provide new information towards developing a feasible and systematic LM 
practices framework which can be applied in the Malaysian automotive component industry.

\section{ACKNOWLEDGEMENT}

The authors would like to thank Proton Berhad, SMECorp Malaysia and Malaysia Automotive Institute for supporting this research.

\section{REFERENCES}

Achanga, P., Shehab, E., Roy, R., \& Nelder, G. (2006). Critical success factors for lean implementation within SMEs. Journal of Manufacturing Technology Management, 17(4), 460-471.

Bhasin, S. \& Burcher, P. (2006). Lean viewed as a philosophy. Journal of Manufacturing Technology Management, 17(1), 56-72.

Bonavia, T. \& Marin, J. A. (2006). An empirical study of lean production in the ceramic tile industry in Spain. International Journal of Operations and Production Management, 26(5), 505-531.

Ferdousi, F. \& Ahmed, A. (2009). An investigation of manufacturing performance improvement through lean production: A study on Bangladeshi garment firms. International Journal of Business and Management, 4(9), 106-114.

Gunasekaran, A., Forker, L., \& Kobu, B. (2000). Improving operations performance in a small company: a case study. International Journal of Operations and Production Management, 20(3), 316-335.

Haniff, M. H. M., Ismail, A. R., Deros, B. M., Rahman, M. N. A., \& Kadirgama, K. (2011). The taguchi approach in optimizing the environmental factors towards productivity at automotive industry. International Journal of Automotive and Mechanical Engineering, 3, 306-317.

Jusoh, R., Ibrahim, D. N., \& Zainuddin, Y. (2008). The performance consequence of multiple performance measures usage: evidence from the Malaysian manufacturers. International Journal of Productivity and Performance Management, 57(2), 119-136.

Kumar, M. \& Antony, A. (2008). Comparing the quality management practices in UK SMEs. Industrial Management and Data Systems 108(9), 1153-1166.

Lee, C. Y. (1997). JIT adoption by small manufacturers in Korea. Journal of Small Business Management, 35(3), 98-107.

Matson, J. E. \& Matson, J. O. (2007). Just-in-time implementation issues among automotive suppliers in the southern USA. Supply Chain Management: An International Journal, 12(6), 432-443.

Melton, T. (2005). The benefits of lean manufacturing. What lean thinking has to offer the process industries. Chemical Engineering Research and Design, 83(A6), 662-673.

Ohno, T. (1988). The Toyota Production System. English translation. Productivity Press.

Pavnaskar, S. J., Gershenson, J. K., \& Jambekar, A. B. (2003). Classification scheme for lean manufacturing tools. International Journal Production Research, 41(13), 3075-3090.

Papadopoulu, T. C. \& Ozbayrak, M. (2005). Leanness: experiences from the journey to date. Journal of Manufacturing Technology Management, 16(7), 784-806. 
Rineheart, J., Huxley, C., \& Robertson, D. (1997). Just another car factory? Lean production and its contents. Cornell University Press.

Rose, M. A. N. M., Deros, B. M., \& Rahman, M. N. A. (2013). Lean manufacturing perceptions and actual practice among Malaysian SMES in automotive industry. International Journal of Automotive and Mechanical Engineering, 7, 820-829.

Rose, A. M. N, Deros, B. Md., \& Rahman, M. N. A. (2010). Development of framework for lean manufacturing implementation in SMEs. $11^{\text {th }}$ Asia Pacific Industrial Engineering and Management System Conference.

Sakakibara, S., Flynn, B. B., Schroeder, R. C., \& Morris, W. T. (1997). The impact of just-in-time manufacturing and its infrastructure on manufacturing performance. Management Science, 43(9),1246-1257.

Shah, R. \& Ward, P. T. (2007). Defining and developing measures of lean production. Journal of Operations Management, 25, 785-805.

Shah, R. \& Ward, P. T. (2003). Lean manufacturing context, practice bundles and performance. Journal of Operations Management, 21(12),129-149.

White, R. E., Pearson, J. N., \& Wilson, J. R. (1999). JIT manufacturing: A survey of implementations in small and large U.S. manufacturers. Management Science, $45(1), 1-14$.

Womack, J., Jones, D. T., \& Roos, D. (1990). The machine that changed the world. New York: Rawson Associates.

Wong, Y. C., Wong, K. Y., \& Ali, A. (2009). A study on lean manufacturing implementation in the Malaysia electrical and electronics industry. European Journal of Scientific Research, 38(4), 521-535.

Zen, M. \& Williamson, P. J. (2003). Hidden dragons. Harvard Business Review, 10, 9299. 